\title{
Supervision Strategies for Improving Community Welfare Program in East Indonesia Area
}

\author{
Herlina Sakawati \\ Lecturer at Public Administration Study Program, Social Science Faculty, Universitas Negeri Makassar \\ (email: herlinamappakanro@gmail.com)

\section{Sulmiah} \\ Lecturer at Public Administration Study Program, Social Science Faculty, Universitas Negeri Makassar \\ (email: Sulmiah@unm.ac.id, 33novasopiaa@gmail.com,wiwidyawaty150305@gmail.com)
}

\section{Novayanti Sopia Rukmana}

Lecturer at Public Administration Study Program, Social Science Faculty, Universitas Negeri Makassar (email: novasopiaa@gmail.com)

\section{Widyawati}

Lecturer at Public Administration Study Program, Social Science Faculty, Universitas Negeri Makassar (email: wiwidyawaty150305@gmail.com)

\begin{abstract}
Various programs to improve community welfare established by the government exist as an effort to solve the problem of poverty, the implementation of which must be accompanied by effective supervision so that the objectives of the program can be achieved. This article aims to explain the monitoring strategy for the implementation of programs to improve community welfare, by selecting the people's salt business program in the Eastern Indonesia region as a case study. The qualitative research method was carried out through interviews and observations, which were then strengthened by secondary data on the strategy of monitoring the people's salt business program. The findings in the field show that the implementation of supervision of the people's salt business program can run optimally, if the stakeholders involved in the supervisory task continue to coordinate well, carry out supervision according to a predetermined time, form a Coordination and Coordination Team in accordance with the direction of the Minister of Marine Affairs and Fishery. In addition, it is necessary to increase the number of employees, as well as to guarantee employee safety while carrying out supervisory duties.
\end{abstract}

\section{Keywords:}

Program; supervision; people's salt business

\section{Introduction}

The welfare policy aims to optimize the role of the state in helping and encouraging people to achieve a better standard of living (Guy, 2015; Suryono, 2014). The welfare policy is explicitly directed at cash transfer programs (Riccucci, Meyers, Lurie, \& Han, 2004). However, since the welfare policy reforms, the focus of policy has been emphasized on the importance 
of work and self-sufficiency in order to achieve a quality of life, (Ewalt \& Jennings, 2004; Riccucci, Meyers, Lurie, \& Han, 2004; Hayward, 1998; Ko, 2015; Blank \& Haskins, 2001).

Even though the welfare program in Indonesia still applies a cash transfer program (Khomaini, 2020; Iping, 2020; Rachman, Agustian, \& Wahyudi, 2018), it does not mean that there are no welfare programs that focus on the importance of work and independence. The people's salt business program (PUGaR) which is a form of realization of the policies of the Minister of Marine Affairs and Fisheries, in increasing national salt self-sufficiency, (Kurniawan \& Azizi, 2012; Haidawati, Fachry, \& Arief, 2014; Dharmayanti, Suhartono, \& Rifin, 2013), since 2016 no longer provides direct assistance to salt farmers. The assistance provided was in the form of goods used to integrate salt fields. This is done so that the assistance provided is not misused.

Regardless of how well policies are made, there is always the possibility that they will be implemented poorly (Ewalt \& Jennings, 2004), as happened in the eastern part of Indonesia. The provision of geomembrane plastic aid which aims to improve the quality of salt is not used properly. This is because salt farmers find it difficult when using geomembrane pallets, where when the rain suddenly comes, they must immediately roll up the plastic, and put it back when the weather starts to improve, besides that the harvest time is longer when compared to using the traditional method, so that plastic geomembranes that have been given are only stored in the warehouse.

Responding to the problems in implementing the PUGaR, the government needs to improve the supervision strategy. This is because of all the management functions that are important in implementing a policy or program, it is the supervisory role that has a greater influence, because the supervisory role is not only responsible for administrative work, but is also involved at all stages of program implementation (Mou, 2017; $\mathrm{Ng}$, 2015) so that when a problem occurs in the implementation of the program, it means that something is wrong with the implementation of supervision. In addition, supervision positively affects employee work motivation, which in turn leads to increased work performance $(\mathrm{Ng}, 2015$; Riccucci, Meyers, Lurie, \& Han, 2004). Where this is very important for the parties involved in the supervision of PUGaR.

Apart from the reasons for the importance of implementing supervision of policy, researchers are interested in conducting research on the strategy of monitoring PUGaR 
because previous research generally only examines policy aspects, such as observing the implementation and evaluation of PUGaR, (Erna \& Adriyani, 2019; Deliarnoor, Buchar, \& Felfina , 2018; Sari, 2018; Kurniawan, 2016). So that this research is expected to be able to provide an overview to the government, both central and regional governments, especially the regional government of Jeneponto Regency, regarding a good monitoring strategy to be carried out in order to minimize errors in program implementation, so that the objectives of PUGaR can be achieved.

\section{Methods}

The implementation of the people's salt business program (PUGaR) in Eastern Indonesia which is experiencing problems has prompted researchers to conduct research on surveillance strategies. Because the failure of a program cannot be separated from the implementation of supervision. Therefore, this research was conducted using qualitative methods, because by using this method according to the views (Creswell, 2009), the researcher was able to present accurate research results, which then made it easier for readers to understand the existing problems.

The research data consisted of primary data and secondary data, which were obtained from the results of observations, interviews, and documentation reviews. Informants in this study were determined using the snowball technique, which according to (N Discovery, 2013) the informant was determined based on the information that had been obtained, which then became a reference for determining the next informant. The informants in this study consisted of the Head of the Department of Marine Affairs and Fisheries in Jeneponto Regency, the staff of the Department of Marine Affairs and Fisheries in the Jeneponto Regency, the Fisheries Extension Officer in the Jeneponto Regency, and the salt farmer groups. Furthermore, the research data obtained are analyzed using data analysis techniques from (Miles, Huberman, \& Saldana, 2014) known as interactive models, which consist of data reduction, display data, and conclusions, drawing / verification.

\section{Results and Discussion}

The organizations involved in the implementation of PUGaR supervision in Eastern Indonesia, is Jeneponto Regency, South Sulawesi consist of the Central Government and the 
Local Government. The Central Government, is the Inspectorate General of the Ministry of Marine Affairs and Fisheries. The Regional Government consists of the Department of Marine Affairs and Fisheries of South Sulawesi Province, the Office of Marine Affairs and Fisheries of the Jeneponto Regency, and a part of the Fisheries Extension Officer.

Since in this research the research location is in the district area, the focus of the research is on the supervision carried out by the Jeneponto Regency Marine and Fisheries Office assisted by the Fisheries Extension Officer. This is based on the Ministry of Marine Affairs and Fisheries Decree No. 1 / Kep-DJPRL / 2020 concerning Technical Guidelines for Community Salt Business Development, that the Jeneponto Regency Marine and Fisheries Service has the responsibility to supervise the utilization of PUGaR assistance at the district level. The results of the supervision of the Jeneponto Regency Marine and Fisheries Service will be reported to the Inspectorate General of the Ministry of Marine Affairs and Fisheries, the Department of Marine Affairs and Fisheries of South Sulawesi Province.

Based on the previous discussion, it has been explained that this study aims to explain the monitoring strategy that must be carried out by the Jenepoto Regency Marine and Fisheries Office in the success of PUGaR. Therefore, the researcher uses the theory from (David, 2010), because the theory explains the strategic planning stages, which consist of the input stage and the analysis stage. The input stage is related to the External Factor Evaluation Matrix (EFE) and Internal Factor Evaluation (EFI), while the analysis stage is related to the SWOT Matrix. For more details regarding the PUGaR supervision strategy, it is presented as follows:

\section{Matrix EFE and EFI}

The EFE and EFI matrix analysis on PUGaR supervision in Jeneponto Regency, South Sulawesi, was made based on the results of the identification of internal and external strategic factors in the Office of Marine Affairs and Fisheries, Jeneponto Regency, which consists of strengths, weaknesses, opportunities and threats. The identification of these internal and external strategic factors obtained from the interview results is presented in the following table: 
Table 1.

Strategic Factors

\begin{tabular}{|c|c|c|c|c|}
\hline No & Strength & Weakness & Opportunity & Threat \\
\hline a. & $\begin{array}{l}\text { Has supervision } \\
\text { guidelines for the } \\
\text { Pugar Program issued } \\
\text { by the Ministry of } \\
\text { Marine Affairs and } \\
\text { Fisheries }\end{array}$ & $\begin{array}{l}\text { The number of } \\
\text { extension workers and } \\
\text { staff of the Jeneponto } \\
\text { Regency Fisheries and } \\
\text { Marine Service who } \\
\text { supervises the Pugar } \\
\text { program is not } \\
\text { sufficient }\end{array}$ & $\begin{array}{l}\text { The opportunity } \\
\text { to have a } \\
\text { cooperative } \\
\text { relationship with } \\
\text { the Industry and } \\
\text { Trade Office of } \\
\text { Jeneponto } \\
\text { Regency regarding } \\
\text { salt price } \\
\text { protection. }\end{array}$ & $\begin{array}{l}\text { Lack of trust } \\
\text { from salt } \\
\text { farmer groups } \\
\text { in extension } \\
\text { workers and } \\
\text { agencies } \\
\text { related to the } \\
\text { Pugar } \\
\text { program. }\end{array}$ \\
\hline b. & $\begin{array}{l}\text { Coordinate with the } \\
\text { Department of Marine } \\
\text { Affairs and Fisheries } \\
\text { of South Sulawesi } \\
\text { Province, Inspectorate } \\
\text { of the Ministry of } \\
\text { Marine Affairs and } \\
\text { Fisheries and } \\
\text { Fisheries Extension }\end{array}$ & $\begin{array}{l}\text { The staff of the } \\
\text { Jeneponto Regency } \\
\text { Fisheries and Marine } \\
\text { Service who supervise } \\
\text { the Pugar program do } \\
\text { not comply with their } \\
\text { main duties and } \\
\text { functions }\end{array}$ & $\begin{array}{l}\text { Opportunity to } \\
\text { improve systems, } \\
\text { procedures and } \\
\text { patterns of } \\
\text { supervision in } \\
\text { accordance with } \\
\text { the needs of the } \\
\text { Jeneponto District } \\
\text { government. }\end{array}$ & $\begin{array}{l}\text { The safety of } \\
\text { extension } \\
\text { workers in } \\
\text { carrying out } \\
\text { their tasks is } \\
\text { threatened }\end{array}$ \\
\hline c. & $\begin{array}{l}\text { Have a schedule of } \\
\text { supervision }\end{array}$ & $\begin{array}{l}\text { Fisheries staff and } \\
\text { extension workers do } \\
\text { not take the initiative to } \\
\text { impose sanctions on } \\
\text { groups of salt farmers } \\
\text { who do not use the } \\
\text { assistance provided }\end{array}$ & $\begin{array}{l}\text { Have opportunity } \\
\text { to know the needs } \\
\text { of farmer groups } \\
\text { in improving the } \\
\text { quality and } \\
\text { production of salt }\end{array}$ & $\begin{array}{l}\text { The level of } \\
\text { awareness of } \\
\text { pond farmers } \\
\text { to produce } \\
\text { quality salt is } \\
\text { still low }\end{array}$ \\
\hline
\end{tabular}

Source: Author's Process, 2020

After the strategic factors were identified, they were weighted using the paired comparison method. This aims to determine the level of importance of strategic factors for supervision. The results of weighting strategic factors are presented as follows:

\section{a. Internal Matrix Analysis}

The EFI matrix strategy is a formulation of internal environmental analysis. This matrix provides a summary and evaluation of the main strengths and weaknesses of the Department of Marine Affairs and Fisheries in Jeneponto Regency. The EFI matrix also provides an introduction and evaluation basis for the supervision carried out by the Jeneponto Regency Marine and Fisheries Service together with the Fisheries Extension Officer. The 
results of the analysis on the identification of internal factors of PUGaR supervision in Jeneponto Regency can be seen in the following table:

Tabel 2.

Matrix EFI

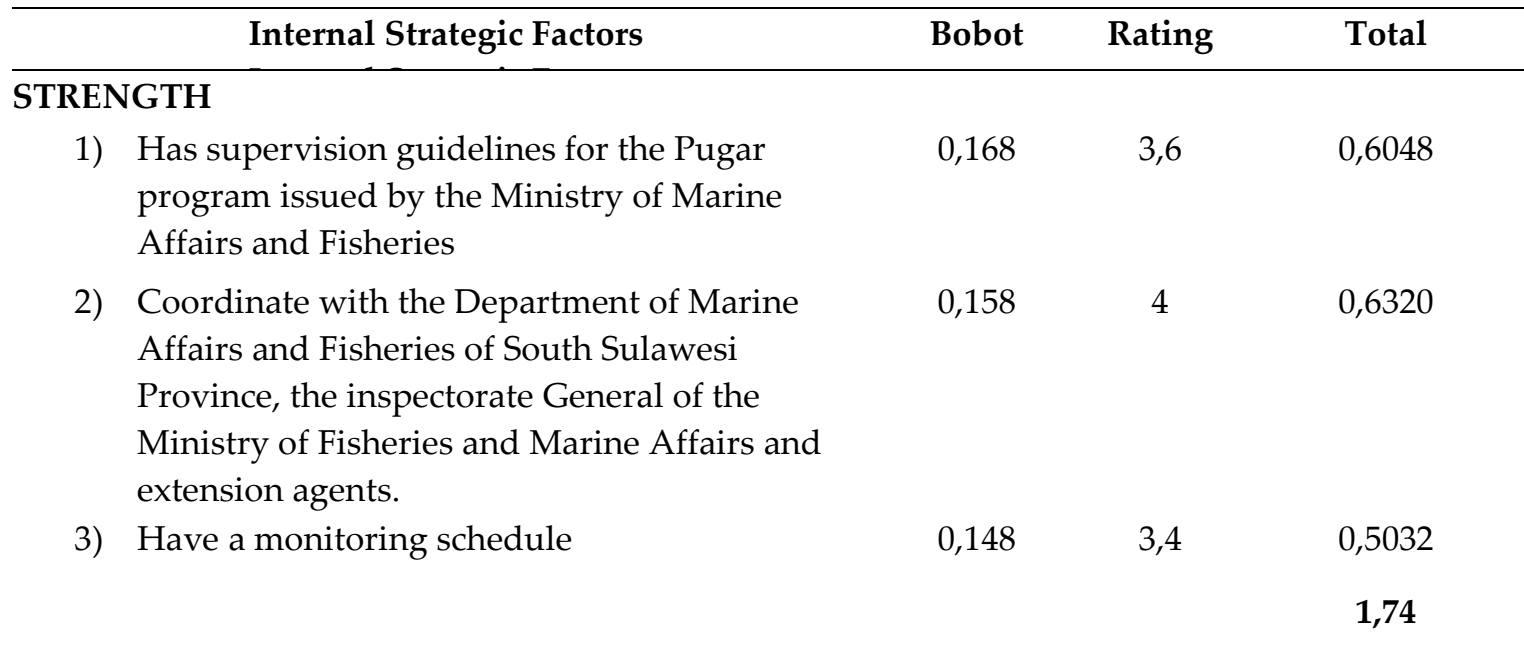

\section{WEAKNESS} Jeneponto Regency Fisheries and Marine Service who supervises the Pugar program is not sufficient

2) The staff of the Jeneponto Regency Fisheries and Marine Service who supervise the Pugar program are not in accordance with their main tasks and functions

3) Fisheries staff and extension workers do not take the initiative to impose sanctions on groups of salt farmers who do not use the assistance provided

\section{Source: Author's Process, 2020}

Based on table 2 above, it can be seen that the main strength of the Jeneponto Regency Marine and Fisheries Service in carrying out PUGaR supervision lies in the coordination carried out with the Inspectorate General of the Ministry of Fisheries and Marine Affairs, the Office of Marine Affairs and Fisheries of South Sulawesi Province, and Fishery Extension Officers in Jeneponto Regency.

In program implementation that involves many stakeholders, the role of coordination is very important. Because with good coordination, there will be no overlapping of authority, chaos, disputes, and various other problems that are not expected in the implementation of PUGaR. One example when coordination does not go well in the implementation of policies 
that involve several stakeholders is the implementation of the development of the Mamminasata urban area in South Sulawesi. Because coordination was not going well, causing chaos in the formulation of spatial plans incorporated in the Mamminasata area, which then hampered the development process (Widyawati, Widianingsih, \& Pancasilawan, 2018).

Coordination carried out by the Department of Marine Affairs and Fisheries of Jeneponto Regency together with the Inspectorate General of the Ministry of Fisheries and Marine Affairs, the Office of Marine Affairs and Fisheries of South Sulawesi Province, as well as the Jeneponto Regency Fisheries Extension Officer, is carried out every 2 times a year, namely between May - June and October - November. . Through the coordination carried out, the cooperation between the organizations involved in implementing PUGaR is wellmaintained.

The implementation guidelines and monitoring schedule, although not included in the main strengths of the Jeneponto Regency Marine and Fisheries Office in carrying out PUGaR supervision, still contribute well to the implementation of PUGaR supervision. When employees have guidelines in carrying out activities, the possibility of errors is very minimal. Guidelines provide an overview to employees what to do in carrying out their role as program supervisor. Then with the supervision schedule, the implementation of supervision can be carried out routinely.

Furthermore, it is related to the main weakness of the Jeneponto Regency Marine and Fisheries Service in carrying out PUGaR supervision, according to table 2 above, namely the minimum number of employees conducting PUGaR supervision. The Head of the Jeneponto Regency Marine and Fisheries Office assigns the responsibility for implementing the PUGaR program to the Facilities and Infrastructure Sector for Capture and Management of Marine Spaces. Of the 4 employees in this field, only 1 person supervises. This is because only this person really understands PUGaR activities. Due to the lack of staff to supervise, the Head of the Office also involved 6 Fishery Extension Officers to help supervise PUGaR, so that the total number of officers who carry out PUGaR supervision in Jeneponto Regency is 7 people.

If it is related to the existing area of salt in Jeneponto Regency, which is $971 \mathrm{Ha}$, it is certainly not proportional to the number of workers who carry out supervision. This then led to an overcapacity workload, so the implementation of supervision did not go well. This is in 
line with the view (Lisnayetti \& Hasanbasri, 2006), that if someone has a high workload, then their performance will decrease. Research results (Rolos, Sambu, \& Rumawas, 2018) also show that a high workload can reduce the potential for employee performance.

\section{b. External Matrix Analysis}

The EFE matrix is used to summarize opportunities and threats to the organization. The EFE matrix analysis is carried out the same as analyzing the IFE matrix, namely the calculation of the weight and rating of each factor. The results of identification of external factors of PUGaR supervision by the Department of Marine Affairs and Fisheries, Jeneponto Regency can be seen in the following table:

Table 3.

Matrix EFE

\begin{tabular}{lccc}
\hline \multicolumn{1}{c}{ External Strategic Factors } & Bobot & Rating & Total \\
$\begin{array}{l}\text { OPPORTUNITY } \\
\text { 1) Have the opportunity to establish salt marketing systems } \\
\text { and procedures and increase production. }\end{array}$ & 0,156 & 3,6 & 0,5616 \\
$\begin{array}{l}\text { 2) The Department of Maritime Affairs and Fisheries has the } \\
\text { opportunity to cooperate with the Jeneponto Regency } \\
\text { Industry and Trade Office regarding salt price protection. }\end{array}$ & 0,172 & 2,8 & 0,4816 \\
$\begin{array}{l}\text { 3) Have the opportunity to know the needs of farmer groups } \\
\text { in improving the quality and production of salt }\end{array}$ & 0,158 & 2 & 0,3160 \\
$\begin{array}{l}\text { THREAT } \\
\text { 1) Lack of trust from salt farmer groups to extension workers } \\
\text { and the Dinas related to the Pugar program. }\end{array}$ & 0,162 & 3 & $\mathbf{1 , 3 5 9 2}$ \\
$\begin{array}{l}\text { 2) The safety of instructors in carrying out their duties is } \\
\text { threatened } \\
\text { 3) the level of awareness of pond farmers to produce quality } \\
\text { salt is still low }\end{array}$ & 0,168 & 2 & 0,3860 \\
\end{tabular}

Source: Author's Process, 2020

In table 3 above, it can be seen that the opportunities that can be carried out by the Jeneponto Regency Marine and Fisheries Office in implementing PUGaR supervision are creating a salt marketing system and procedure and increasing production. In 2019 the salt harvest in Jeneponto Regency is abundant, but it cannot be absorbed in the market. This is because there have been no buyers since the outbreak of the Covid 19 virus. So that farmers 
are forced to pile up their crops in warehouses. In addition, salt farmers still have minimal knowledge about the marketing system. So far, farmers have only marketed their crops by hawking in front of their houses.

Although the opportunity to establish a cooperative relationship with the Jeneponto Regency Industry and Trade Office regarding salt price protection is not included as a major opportunity, the government needs to pay attention to the price of salt, because when salt farmers are able to produce quality salt, it is not accompanied by a high selling price. Besides having an impact on salt farmers, it will also have an impact on the implementation of PUGaR.

One of the reasons why salt farmers prefer to use the traditional method is the low salt price, and there is no difference between the price of salt using the traditional method and the use of geomembrane plastic. When this is allowed to happen, the government's efforts to improve the welfare of the people can fail. As stated by, (Strassheim, 2019; McConnel, 2011), that when the goals of the policies made by the government are not achieved, then the policies are considered failures.

Furthermore, for the third monitoring opportunity, namely knowing the needs of farmer groups in improving salt quality and production, in 2019 it has been able to be carried out properly. The results of the supervision carried out by the Fisheries Extension Officer, namely salt farmers need warehouse assistance for storing their crops. From the results of the supervision, assistance was provided in the form of building a warehouse in Bangkala District, Jeneponto Regency, South Sulawesi.

\section{SWOT analysis}

Based on the analysis of the internal and external environment that has been carried out, what researchers do next is to make a SWOT analysis which aims to provide an insight into the steps that can be taken by the Jeneponto Regency Marine and Fisheries Service in carrying out PUGaR supervision, so that the objectives of PUGaR can be achieved and the welfare of petmabk. salt in Jeneponto Regency is getting better.

The first step the researchers took in conducting a SWOT analysis was creating a SWOT quadrant. This aims to determine the strategies that can be carried out. For determining the location of points in the quadrant, refer to the IFE and EFE matrices that have been presented previously. For more details about the SWOT quadrant, see the following figure: 
Picture 1.

SWOT Quadrant

Quadrant III

Quadrant I

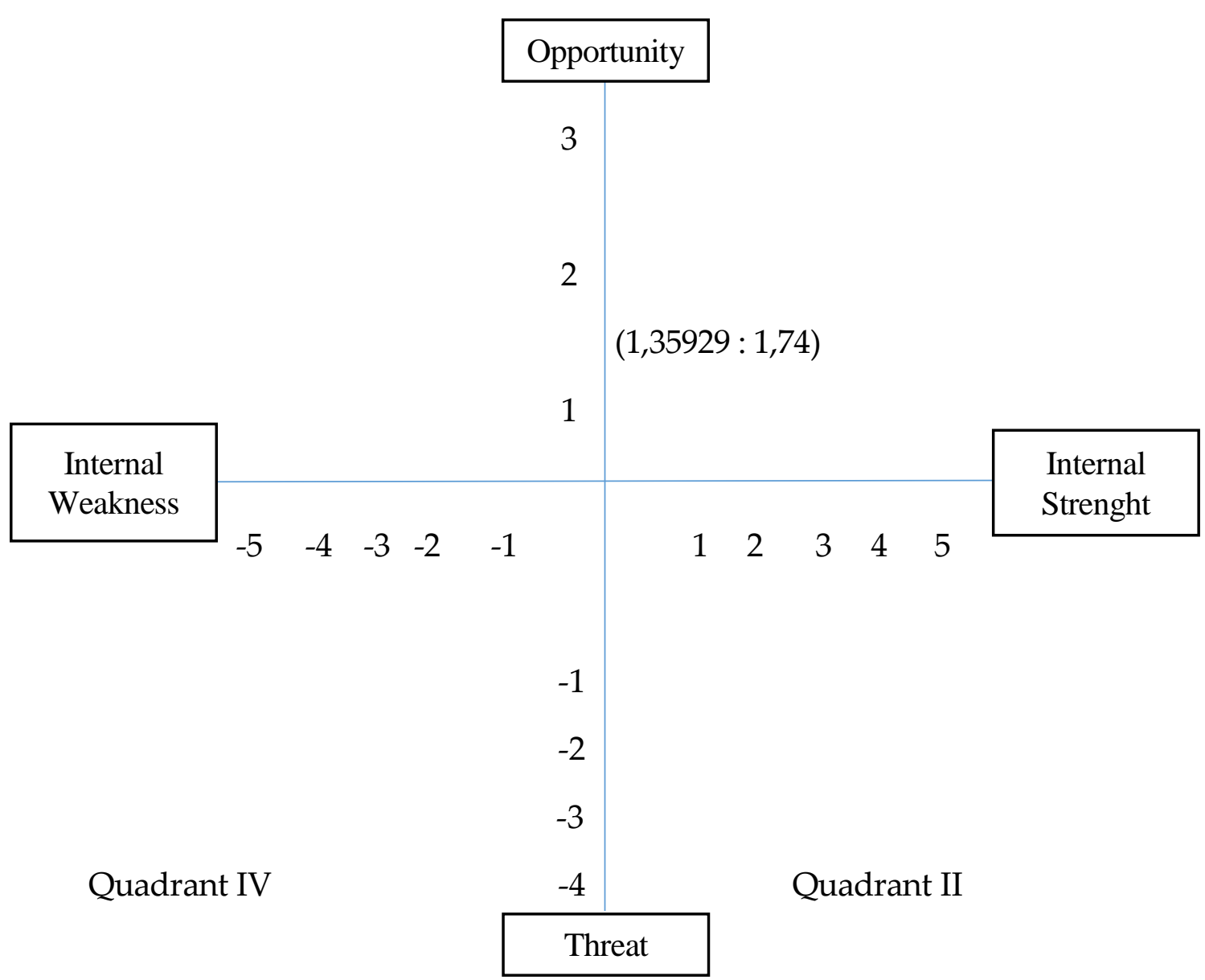

Based on the picture above, it is known that the strategy of the Jeneponto Regency Marine and Fisheries Service is in Quadrant 1, which means that the strategy that must be implemented by the Jeneponto Regency Marine and Fisheries Service is to support aggressive growth policies (Rangkuti, 2013). This means that the Jeneponto Regency Marine and Fisheries Service is in a favorable situation, namely having the strength and opportunity, so that the Jeneponto Regency Marine and Fisheries Service with its internal strength can take advantage of the existing opportunities so that PUGaR supervision can be carried out optimally.

The next step is to create a SWOT matrix, with this matrix it will be easier to formulate various strategies, which are directed at efforts to use strengths, improve weaknesses, take 
advantage of surveillance opportunities and overcome threats. For more details, see the following table.

\section{Internal Factor}

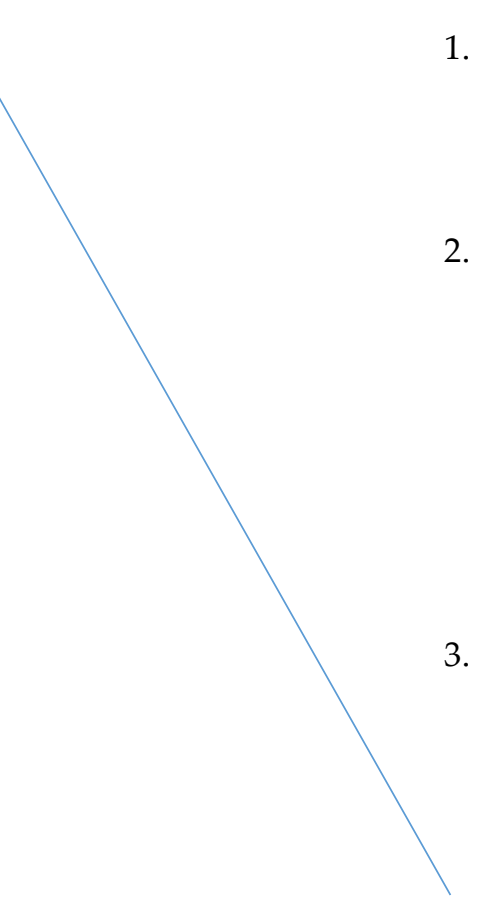

Table 4.

SWOT Matrix Strength (S)

1. Has supervision guidelines for the Pugar program issued by the Ministry of Marine Affairs and Fisheries

2. Coordinate with the Department of Marine Affairs and Fisheries of Soutr Sulawesi Province, the inspectorate General of the Ministry of Fisheries and Marine Affairs and extension agents.

3. Have a monitoring schedule

\section{Weakness (W)}

1. The number of extension officers and staff of the Jeneponto Regency Fisheries and Marine Service who supervises the Pugar program is not sufficient.

2. The staff of the Jeneponto Regency Fisheries and Marine Service who supervise the Pugar program do not comply with their main duties and functions

3. Fisheries staff and extension workers do not take the initiative to impose sanctions on groups of salt farmers who do not use the assistance provided

\section{External}

Factor

\section{Opportunity (O)}

1. Have the opportunity to establish a salt marketing system and procedure and increase production..

2. The Department of Marine Affairs and Fisheries has the opportunity to cooperate with the Jeneponto Regency Industry and

\section{S - O strategy}

1. The Department of Marine Affairs and Fisheries of Jeneponto Regency, together with the Department of Marine Affairs and Fisheries of the Province of South Sulawesi, the Inspectorate of Marine

\section{W - O strategy}

1. Increase the number of staff and fishery extension workers in the implementation of monitoring the utilization of PUGaR assistance

2. Forming a Coordination and Consolidation Team. 
Trade Office regarding salt price protection.

3. Have the opportunity to know the needs of farmer groups in improving the quality and production of salt

Threat (T)

1. Lack of trust from the salt farmer groups in extension workers and the Dinas related to the Pugar program.

2. The safety of the extension personnel in carrying out their duties is threatened.

3. The level of awareness of pond farmers to produce quality salt is still low

Source: Author's Process, 2020
Affairs and Fisheries of the Jeneponto Regency, formulate a more modern marketing strategy so that salt farmers can be distributed not only in South Sulawesi.

2. The Department of Maritime Affairs and Fisheries and the Department of Industry and Trade in Jeneponto Regency proposes the central government to formulate policies related to the protection of local salt prices.

3. Optimizing the implementation of supervision by adhering to the technical guidelines for supervision to better understand the needs of salt farmers.

\section{Stretegi S - T}

W - T strategy

1. Disseminating the new policy regarding PUGaR assistance to salt farmers using various media.

2. Socialize the importance of improving the quality of salt for sales and health.
1. Provide work safety guarantees to employees and extension agents who supervise the utilization of PUGaR assistance.

2. Give sanctions to salt farmer groups that do not use PUGaR assistance properly.

\section{Conclusion}

The implementation of PUGaR supervision in Eastern Indonesia still has constraints that are influenced by the internal and external environment of the organizations responsible for implementing PUGaR at the district level. So that in order to maximize the implementation 
of supervision in achieving the objectives of PUGaR, it is necessary to coordinate in formulating marketing strategies, in collaboration with the Department of Industry and Trade to propose policies related to protection of local salt prices to the central government, recruit PUGaR supervisors, form coordination and co-consolidation teams. In addition, due to changes in the PUGaR assistance system, supervisors need to maximize the implementation of socialization and impose sanctions if the assistance provided is not used.

\section{Reference}

\section{A. Books}

Blank, R. M., \& Haskins, R. (2001). . The New World of. Washington, DC: Brookings Institution. Creswell, J. W. (2009). Research Design: Qualitative, Quantitative, and Mixed Methods Approaches. California: SAGE.

David, F. R. (2010). Strategic Management. Jakarta: Salemba Empat.

Deliarnoor, N. A., Buchar, R. A., \& Felfina, L. K. (2018). Evaluasi Program Usaha Pemberdayaan Usaha Garam Rakyat di Kecamatan Pangenan, Kabupaten Cirebon, Jawa Barat. Responsive, 1(1), 27-33.

Erna, \& Adriyani, R. (2019). Implementasi Kebijakan PUGAR terhadap Kesejahteraan Petani Garam di Pesisir Pantai Kabupaten Cirebon. Cendekia Jaya, 1(1), 1-21.

Ewalt, J. A., \& Jennings, E. T. (2004). Administration, Governance, and Policy Tools in Welfare Policy Implementation. Public Administration Review, 64(4), 449-462.

Guy, A. (2015). Personal values and support of welfare policy among undergraduate students in Israel. International Journal of Social Welfare, 78-85.

Hayward, S. (1998). The Shocking Success of Welfare Reform. Policy Review, 87(1), 6-11.

Iping, B. (2020). Perlindungan Sosial Melalui Kebijakan Program Bantuan Langsung Tunai (BLT) di Era Pandemi Covid-19: Tinjauan Perspektif Ekonomi dan Sosial. Jurnal Manajemen dan Pendidikan dan Ilmu Sosial, 1(2), 516-526.

Khomaini, A. A. (2020). Dampak program Bantuan Tunai ( Cash Transfer) terhadap Kesejahteraan Subjektif di Indonesia. Indonesian Treasury Review: Jurnal Perbendaharaan, Keuangan dan Kebijakan Publik, 5(1), 1-16.

Ko, H. (2015). The Changing Shape of Welfare Policy in Korea: Analysis of Break Point in the Welfare Budget. Asian Social Work and Policy Review, 151-162. 
Kurniawan, B. A. (2016). Implementasi Program Dana Bantuan Pemberdayaan Usaha Garam Rakyat (PUGAR) dalam Rangka Pengembangan Wirausaha Garam Rakyat (Studi Pada Dinas Kelautan dan Perikanan Kabupaten Sumenep). AJIE - Asian Journal of Innovation and Entrepreneurship, 1(1), 12-29.

Lisnayetti, \& Hasanbasri, M. (2006). Beban Kerja dan Kinerja Dosen Poltekes. Padang: PT. Bumi Aksara.

McConnel. (2011). Understanding Policy Success. Basingstoke: Palgrave.

Miles, M., Huberman, A. M., \& Saldana, J. (2014). Qualitative Data Analysis: A Method Sourcebook. New York: Routledge.

Mou, Y. (2017). Overseeing Criminal Justice: The Supervisory Role of the Public Prosecution Service in China. Journal Of Law And Society, 44(4), 620-645.

Nemuan, W. (2013). Metodologi Penelitian Sosial: Pendekatan Kualitatif dan Kuantitatif, Edisi 7. Jakarta Barat: PT. Indeks.

Ng, K. H. (2015). Supervisory Practices and Training Transfer: Lessons from Malaysia. Asia Pacific Journal of Human Resources, 221-240.

Rachman, B., Agustian, A., \& Wahyudi. (2018). Efektivitas dan Perspektif Pelaksanaan Program Beras Sejahtera (Rasta dan Bantuan Pangan Non-Tunai (BPNT). Analisis Kebijakan Pertanian, 16(1), 1-18.

Rangkuti, F. (2013). Teknik Membedah Kasus Bisnis Analisis SWOT Cara, Perhitungan Bobot, Rating dan OCAI. Jakarta: Gramedia Pustaka Utama.

Riccucci, N. M., Meyers, M. K., Lurie, I., \& Han, J. S. (2004). The Implementation of Welfare Reform Policy: The Role of Public Managers in Front-Line Practices. Public Administration Review, 64(4), 438-448.

Rolos, J. K., Sambu, S. A., \& Rumawas, W. (2018). Pengaruh Beban Kerja Terhadap Kinerja Karyawan Pada PT. Asuransi Jiwasraya Cabang Manado Kota. Jurnal Administrasi Bisnis, 6(4), 19-27.

Sari, Y. R. (2018). Implementasi Program Pemberdayaan Usaha Garam Rakyat (PUGAR) di Desa Kedungmutih Kecamatan Wedung Kabupaten Demak Tahun 2011- 2013. Spirit Publik, 13(1), 17-37.

Siagian, S. P. (2014). Manajemen Sumber Daya Manusia. Jakarta: Bumi Aksara. 
Strassheim, H. (2019). Behavioural mechanisms and public policy design: Preventing failures in behavioural public policy. Public Policy and Administration, 0(0), 1-18.

Suryono, A. (2014). Kebijakan Publik untuk Kesejahteraan Rakyat. Transparansi: Jurnal Ilmiah Ilmu Administrasi, 6(2), 98-102.

Widyawati, Widianingsih, I., \& Pancasilawan, R. (2018). Jaringan Organisasi dalam Pembangunan Kawasan Perkotaan Mamminasata, Provinsi Sulawesi Selatan. Jurnal Ilmiah Ilmu Administrasi Publik: Jurnal Pemikiran dan Penelitian Administrasi Publik, 8(1), $11-20$. 